\title{
Guidance and Counseling Services for Kindergarten
}

\author{
Alizamar Alizamar \\ Department Guidance and Counseling \\ Faculty of Education, Universitas Negeri Padang \\ Jl. Prof. Dr. Hamka Air Tawar Padang. West Sumatera, \\ Indonesia \\ alizamar@konselor.org
}

Afdal Afdal

Department Guidance and Counseling

Faculty of Education, Universitas Negeri Padang

J1. Prof. Dr. Hamka Air Tawar Padang. West Sumatera, Indonesia

afdal@konselor.org

\begin{abstract}
The purpose of education in kindergarten in general is to help the growth and development of physical and spiritual to have readiness in entering further education, develop personality and self-potential in accordance with the stage of development of learners and help lay the groundwork toward the development of attitude, knowledge, skills, and the creative power required by the students to adapt to their environment and to further growth and development. In an effort to achieve the goal of education, it is possible students have various psychological problems that require the existence of guidance and counseling services. For that, it needs a deep and thorough understanding of the implementation of guidance and counseling in kindergarten. This paper discusses the theoretical importance of counseling and guidance services in kindergarten, preparation and implementation and evaluation of guidance and counseling programs in kindergarten.
\end{abstract}

Keywords--guidance and counseling services; kindergarten

\section{INTRODUCTION}

The law of the national education system of Indonesia in 2003 implies the existence of guarantees for the implementation of early childhood education properly and programmed. Early childhood education is defined as a coaching effort aimed at children from birth up to the age of six that is done through the provision of educational stimuli to assist growth and physical and spiritual development so that children have readiness in entering further education. Kindergarten as one type of early childhood education services, further regulated Regulation of the Minister of Education and Culture of the Republic of Indonesia No. 146 of 2014 on Curriculum 2013 Early Childhood Education. In the regulation, it is explained that the curriculum of early childhood education in kindergarten education contains core competence and basic competence in terms of Spiritual Attitude, Social Attitude, Knowledge and Skills. The competencies in question include development programs in (a). religious and moral values; (b) physical-motor; (c). cognitive; (d.) language; (e) social-emotional; and (f) the arts development program. The minister's regulation implies

\author{
Ifdil Ifdil \\ Department Guidance and Counseling \\ Faculty of Education, Universitas Negeri Padang \\ Jl. Prof. Dr. Hamka Air Tawar Padang. West Sumatera, \\ Indonesia \\ Ifdil@,konselor.org
}

the need to consider several principles in the preparation of the early childhood curriculum (a) child-centered, (b) contextual, (c) comprehensive, integrated, and sustainable, (d) become the basis for the formation of the child's personality as a whole; (e) (f) consider the way children learn from simple to complex, concrete to abstract, from verbal to movement, and from social kerasa acknowledgment, (g) consider the integration of aspects in the integrated development of the child's ie, education, health and nutrition, parenting, and child protection, (h) using learning approaches through play that are fun, functional, and effective learning for children; (i) provide a child's learning experience by taking note of and utilizing science, technology and art that develops dynamically and (j) takes into account the socio-cultural characteristics of local communities and supports the preservation of cultural diversity. In its implementation, Early Childhood Education services in Indonesia are organized by age group and type of services, one of which is Early Childhood Education Services for ages 4 (four) up to 6 (six) years consisting of kindergartens /Raudhatul Athfal (RA ) / Bustanul Athfal (BA), and the equivalent.

Programs set up by the government indicate that the purpose of education in kindergarten in general to help the growth and development of physical and spiritual children to have readiness in entering further education, develop personality and self potential according to the stage of child development and help lay the foundation to the direction of development of attitudes, knowledge, skills, and creativity required by the child in adjusting to his environment and for further growth and development. During this time, in Indonesia kindergarten students are expected to adjust quickly to the school environment, and asked to learn to follow the rules, listening to teachers, work independently, and also expected to work together with classmates to achieve at the same speed, and build a positive relationship with teachers and other students, but in reality many children do not form satisfactory relationships with their teachers and classmates and do not acquire the same 
academic skills with their peers [1]. This condition certainly raises various problems in the achievement of national education objectives. The phenomenon in the field that is in the kindergarten education found there are various psychological problems experienced by early childhood such as attitude that likes to oppose, force and demand [2], often annoying his friend, experiencing speech delay, communication difficulties, and early childhood experience psychological pressure in school as in bullying by his friends, early childhood mimics bullying behavior that has occurred in his environment [3]

Furthermore, Bunu in 2012 discloses that there are some problems that occur in kindergarten children include: (1) Social Problems such as: (a) selfish, eg thinking and talking about yourself, and likes to set up friends, want to win alone, (b) quarreling, for example, often quarreling in groups, giving physical opposition, refusing to participate in groups, and (c) aggressive eg kicking and hitting friends; (2) Emotional problems experienced by kindergarten children are (a) anxious, eg not wanting to part with the introduction, (b) shy do not want to be friends, (c) awkward, eg reddening when addressed, and (d) fear, for example expressing expression fear; (3) Moral matters such as (a) cheating, including in this case deceiving friends in play, lying, (b) stealing, such as taking things without a permit, (c) destructing, eg deliberately destroying a friend's toy; (4) Developmental problems, such as the difficulty of understanding people's speech and being slow in understanding explanations, and (5) language problems, where speech development is below the child's developmental level, speaks quickly so that it is difficult to understand, and has relatively little vocabulary compared to his age friends. Furthermore, Setianingrum's research in 2016 also explains that early childhood experienced problems in motor development such as problems in collage work and arranging blocks [5]. If such things are left then it will affect the motor development of these early childhood. As found in the following studies, it is found that children have low motor skills [6] [7] and motor development is not optimal [8].

These problems, suggesting the need for a systematic and comprehensive education effort (in this case of kindergarten education) to help students achieve a great personality, character and live their lives effectively. Education in kindergarten is an early education before entering primary education. If the kindergarten education occurs problems, it will affect the next education. Negative experiences in childhood have an impact until the child enters adulthood. One of the major impacts children can face if not handled properly in kindergarten is the underachiver [9]. Martin (2014) said the lack of fulfillment of developmental tasks in the past resulted in adolescents now experiencing moral or moral crisis.

The Saputra \& Setianingrum research [11] conducted at Cendekia Kids School found that there were children aged 3-4 years who had mild motor development problems, the first subjects experienced fine motor problems in collage activity while the second subjects experienced fine motor problems in the activities of collating blocks. The problem of delayed development of fine motor should be addressed immediately, one way to overcome it is by counseling intervention. Facts in the field mentioned Guidance and Counseling services in kindergarten is as important as Guidance and Counseling in high school. However, the pressure between the two is different, the pressure of each service Guidance and Counseling is always in accordance with the level or level of education of the students concerned [24].

From the results of previous research the existence of Guidance and Counseling in early childhood environment is actually very necessary because many behavioral problems appear in the students during adulthood caused by his past in a small time [12]. Counseling and Counseling Services in kindergarten aims to help kindergarten children achieve their developmental tasks as children. In an effort to serve the kindergarten children facing developmental tasks, Guidance and counseling services seeks to do various preventive activities against something that will hamper the child in achieving development tasks owned by kindergarten children.

\section{GUIDANCE AND COUNSELING IN INDONESIA NATIONAL EDUCATION SYSTEM}

The 2003 National Education System Act explains that guidance and counseling is an integrated part of national education. The counseling and guidance counselor is BK teacher or counselor. In the educational environment, learners are required to master various abilities or competencies, whether related to the subject, as well as related to personal, social, and career development of his life. In order for learners to achieve optimal development, optimal service is required also from every element of education, especially in schools.

Prayitno [21]-[24] defines guidance and counseling as a support service for students, individually or in groups to be self-sustaining and able to develop optimally, in personal, social, learning and career guidance through various types of support services and activities based on prevailing norms .Then Kamaluddin explains that Guidance and Counseling is a proactive and systematic effort in facilitating individuals to achieve optimal levels of development, development of effective behavior, environmental development, and enhancement of the function or benefit of individuals in their environment [22].

Guidance and Counseling holds an important task and responsibility for developing the environment, building dynamic interaction between individuals and the environment, teaching individuals to develop, change and improve behavior. Prayitno mentions ten types of guidance and counseling services: 1) orientation services 2) information services, 3) placement services, 4) content mastery services, 5) individual counseling services, 6) group guidance services 7) group counseling services, 8) consulting services; 9) mediation services, and 10) advocacy services. The 10 types of counseling and guidance services in intent, organized for the eradication of student problems in the personal, social, academic, and career fields [21] [24]. 


\section{GUIDANCE AND COUNSELING SERVICES IN KINDERGARTEN}

Formally the existence of Guidance and Counseling in kindergarten is recognized since the enactment of the curriculum of kindergarten 1976, which is expressly stated in book III c curriculum kindergarten 1976. In Curriculum 1994 also affirmed the implementation of Guidance and Counseling in kindergarten implemented integrated in everyday study activity in kindergarten. Thus the implementation of Guidance and Counseling in kindergarten is done by the classroom teacher who doubles as a mentor teacher, so kindergarten teachers perform two tasks simultaneously, namely: teaching and guiding [13].

Implementation of guidance and counseling on children of age has the following principles:

a. Guidance becomes an important part of the educational process

In this case, guidance and counseling in addition to related to early childhood learning activities are also more oriented to not be linked various other activities that support the growth and development of children.

b. Guidance is given to all children and not just to children with problems

All students need help, whether they have no problems or children who have problems. Children who are considered to have no problems, but still need guidance because children need to keep developing the ability that is in him. Assistance given to such children is prevention and development. While the guidance for the troubled child is more of an improvement.

c. Guidance is a unified process in all educational activities Implementation of guidance in early childhood cannot be separated in the whole learning process. When teachers carry out teaching and training activities, teachers can also carry out the process of counseling using learning methods that are often used in teaching.

d. Guidance should center on the mentored child

The clarity of direction to whom the guidance process is carried out will bring about good results from a process undertaken. Teachers should not carelessly provide guidance, guidance that teachers should be motivated understanding of the conditions of the child's problems

e. Guidance activities cover all abilities of child development that include physical-motor skills, intelligence, social and emotional

Guidance on early childhood education needs to be oriented to all aspects of child development, not just concentrating on one aspect of development alone. Inhibition of the development of one of the aspects that exist in the child can inhibit the development of other aspects.

f. Guidance must begin by identifying the child's perceived needs

Guidance for early childhood begins by identifying the various needs of the child because each child has different needs. Fulfillment needs through the process of guidance will support the next child development process.

g. Guidance should be flexible and appropriate to the needs and development of children

teachers / counselors cannot provide guidance with the same approach in each child because the needs and development of each other's children is different.

h. In conveying child issues to parents should create a safe and pleasant situation so as to enable reasonable communication and avoid misunderstanding

The problem with early childhood is a problem that cannot be separated from the role of parents at home because the problem of children is often associated with the problems that exist in the family. Submission of child problems to parents need to be delivered in a straightforward manner does not offend parents so avoid parents' misunderstanding of the teacher.

i. In carrying out guidance activities parents should be included so that they can follow developments and provide assistance to their children at home

Handling by teachers / assistants without the support and cooperation of parents at home will make the problems faced by children cannot be resolved appropriately. This can happen because of the different treatment received by the child when the child is learning with the teacher / escort and when the child is at home. Differences in this treatment will make it more difficult for children to solve the problem.

j. Guidance is done as optimal as possible in accordance with the ability of the teacher / assistant as the guidance counselor, when the problem that occurs need to be followed up then the supervising teacher should consult the principal and experts

In an effort to provide assistance to children, teachers / counselors can work with others who are more competent to assist the development of children. This cooperation can be done with doctors, psychologists, psychiatrists or other experts who have to do with various problems faced by the child.

$\mathrm{k}$. Guidance should be given on an ongoing basis

Guidance is not only done when there are various problems faced by children, but guidance needs to be done continuously and always oriented to efforts to help the child's development as optimal as possible [14]

Guidance and counseling services provided to early childhood aims at the development of early childhood cognitive, motor, social and poverty. Implementation of guidance and counseling in kindergarten does not yet have a standardized standard of reference from the education office [15]. Implementation of guidance and counseling in kindergarten is the development of each foundation / school. In the implementation of guidance and counseling program integrated with the learning process in the classroom, it is implemented based on the theme of learning (especially in the implementation of the field of guidance and information service delivery). 
Areas of guidance that can be implemented for early childhood that is the field of personal, social, learning, career, kinship and religious guidance. Implementation of this field tends to be done in the process of learning in the classroom delivered by the homeroom / teacher center. The area of counsel that is most attention is the field of religious guidance; this is because the school where the research is schools based on the development of religious values / Islamic schools. If other areas of guidance are only implemented following the theme of learning in the classroom, the field of religious guidance is not only implemented through the theme of learning but also implemented in the daily activities of students in school.

Guidance counseling in kindergarten is directed to meet the physical, social and emotional needs of children who are specially designed and tailored to the characteristics of kindergarten children who love to play. Implementation of $\mathrm{BK}$ in kindergarten is done through the process of playing [16] and can be organized through good collaboration through collaborative guidance and counseling [27]. With this play activity the child is directly involved in the guidance activities. The purpose of guidance is to help each child succeed in adjusting to life in school and society [13]. Guidance services are for all children, not just for children with problems such as learning problems, behavioral disorders, and emotional disturbance. Normal children also need guidance to develop their attitude and personality. Gifted, talented children also need guidance to develop them, and find the right tools for their self-development. A Counseling and guidance service in kindergarten aims to help kindergarten children achieve their developmental tasks as a child. Counseling guidance services in kindergarten facilitate the development and growth of children. Kindergarten children are individuals who have various potentials. Disturbance or impairment of the potential development of children will lead to problems in children [13]. Then Prasetiawan [10] also explained that Guidance and Counseling service since early age (elementary level) is specifically aimed at helping students to fulfill the developmental tasks covering the personal, social, educational (learning), and career aspects according to the demands of the environment. However, there needs to be an assessment needs based on the tasks of child development in the formulation of the program, and the need for socialization of guidance and counseling program to build commitment in or role division in the implementation of guidance .

\section{SUMMARY}

Education in kindergarten is an early education before entering primary education. If the kindergarten education occurs problems, it will affect the next education. Therefore there should be a special handling of the development and prevention for kindergarten children. one way to provide guidance and counseling services for kindergarten children in accordance with the stage of development, where guidance and counseling services are given to all or often in the know with Guidance and Counseling for all.

\section{References}

[1] K. Draper, J. White, T. E. O. Shaughnessy, M. Flynt, And N. Jones, "Kinder Training: Play-Based Consultation To Improve The School Adjustment Of Discouraged Kindergarten And First Grade Students Kay Draper Mary Flynt And Nancy Jones," Int. J. Play Ther., Vol. 10, No. 1, Pp. 1-29, 2001.

[2] A. Sudono, Sumber Belajar Dan Alat Permainan Untuk Pendidikan Anak Usia Dini. Grasindo, 2000.

[3] I. Khasanah, "Program 'Sahabat' Sebagai Salah Satu Program Alternatif Penanganan Bullying Pada Anak Usia Dini," J. Pendidik. Anak, Vol. 2, No. 2, 2013.

[4] H. Y. Bunu, "Masalah Anak Taman Kanak-Kanak Menurut Guru Dan Orang Tua Serta Implementasiya Dalam Bimbingan Dan Konseling," J. Bimbing. Konseling, Vol. 1, No. 2, Pp. 108-116, 2012 .

[5] W. N. E. Saputra And I. Setianingrum, "Perkembangan Motorik Halus Anak Usia 3-4 Tahun Di Kelompok Bermain Cendekia Kids School Madiun Dan Implikasinya Pada Layanan Konseling," $J$. Care, Vol. 03, No. 2, Pp. 1-11, 2016.

[6] E. K. Sari, "Peningkatan Perkembangan Motorik Halus Anak Melalui Kegiatan Kolase Dari Bahan Bekas Di Taman Kanak-Kanak Aisyiyah,” J. Pesona Paud, Vol. 1, No. 02, 2012.

[7] L. Indraswari, "Peningkatan Perkembangan Motorik Halus Anak Usia Dini Melalaui Kegiatan Mozaik Di Taman Kanak-Kanak Pembina Agam," J. Pesona Paud, Vol. 1, No. 1, Pp. 1-13, 2012.

[8] L. Vitamami, "Peningkatan Kemampuan Motorik Halus Dengan Finger Painting Pada Kelompok A2 Ra Babussalam Krian Sidoarjo," Paud Teratai, Vol. 2, No. 1, 2013.

[9] R. Rahmawati, "Bimbingan Dan Konseling Untuk Anak Underachiever," Paradigma, Vol. 15, No. Viii, Pp. 1-24, 2013.

[10] Martin, "Program Bimbingan Dan Konseling (Bk) Berbasis TugasTugas Perkembangan Di Taman Kanak- Kanak (Tk)," J. Pendidik. Sos., Vol. 1, No. 1, Pp. 45-58, 2014.

[11] S. Widiasari, I. Susiati, And Wahyu N. E. Saputra, "Play Therapy Berbasis Kearifan Lokal: Peluang Implementasi Teknik Konseling Di Pendidikan Anak Usia Dini,” J. Care, Vol. 04, No. 1, Pp. 61-68, 2016.

[12] M. I. Kholili And E. Christiana, "Evaluasi Pelaksanaan Program Bimbingan Dan Konseling Untuk Anak Usia Dini Kelompok B Di Taman Kanak-Kanak ( $\mathrm{Tk}$ ) Islam Surabaya Evaluation On Implementating Of Guidance And Counseling Program For Group B Early Childhood At Taman Kanak-Kanak ( Tk ) Islam S," J. Bk Unesa, Vol. 4, No. 1, Pp. 33-46, 2013.

[13] K. Suranata And M. Sulastri, "Masalah-Masalah Yang Dialami Anak Usia Dini Dan Implikasinya Bagi Pelaksanaan Bimbingan Dan Konseling Di Taman Kanak-Kanak," J. Pendidik. Dan Pengajaran, Vol. 43, No. 1, Pp. 89-95, 2010.

[14] E. Syaodih And M. Agustin, "Bimbingan Konseling Untuk Anak Usia Dini," 2014. 
[15] M. Agustin, "Hakikat Bimbingan Dan Konseling Untuk Anak Usia Dini,” In Modul, Vol. 1, 2014, Pp. 1-31.

[16] Syahniar, "Tingkah Laku Sosial Anak Tk Serta Implikasinya Bagi Bimbingan Dan Konseling," Pedagogi, Vol. X, No. 2, Pp. 29-35, 2010.

[17] H. Prasetiawan, "Peran Bimbingan Dan Konseling Dalam Pendidikan Ramah Anak Terhadap Pembentukan Karakter Sejak Usia Dini," Junal Care Child. Advis. Res. Educ., Vol. 04, No. 1, Pp. 50-60, 2016.

[18] Zakaria, A. Pelaksanaan Layanan Penempatan Dan Penyaluran Untuk Peningkatan Potensi Non Akademik Anak Usia Dini Kelompok A Di Tk Insan Taqwa. Jurnal Bk Unesa, 4(2). (2014)

[28] Sudono, A. Sumber Belajar Dan Alat Permainan Untuk Pendidikan Anak Usia Dini. Jakarta: Grasindo. 2000.

[38] Suyadi. Buku Pegangan Bimbingan Dan Konseling Untuk Paud (Pendidikan Anak Usia Dini). Jogjakarta : Diva Press, 2009.

[48] Prayitno Dkk, Pembelajaran Melalui Pelayanan Bk Di Satuan Pendidikan. Yogyakarta: Pramitra Publishing, 2015.

[58] Prayitno, Layanan Bimbingan Dan Konseling. Padang: Unp Padang, 2005.

[68] Prayitno, Seri Pemandu Pelayanan Bimbingan Dan Konseling Di Sekolah. Padang: Ikip Padang, 1998.

[78] Kamaluddin, H. (2011). Bimbingan Dan Konseling Sekolah. Jurnal Pendidikan Dan Kebudayaan, 17(4), 447-454.

[88] Zakaria, A. (2014). Pelaksanaan Layanan Penempatan Dan Penyaluran Untuk Peningkatan Potensi Non Akademik Anak Usia Dini Kelompok A Di Tk Insan Taqwa. Jurnal Bk Unesa, 4(2).

[98] A. Afdal, Kolaboratif: Kerangka Kerja Konselor Masa Depan. Jurnal Konseling Dan Pendidikan, Vol. 3, No. 2, Pp. 1-7, 2015. 